\title{
Prototype Sistem informasi Bursa Kerja pada Universitas Serang Raya
}

\author{
Agus Irawan ${ }^{1}$ \\ Rudianto $^{* 2}$ \\ Rizka Desiana $^{3}$ \\ ${ }^{1}$ Program Studi Rekayasa Sistem Komputer Fakultas Sains dan Teknologi Univesitas \\ Serang Raya \\ ${ }^{2}$ Program Studi Teknik Informatika Fakultas Sains dan Teknologi Universitas Banten \\ Jaya \\ ${ }^{3}$ Program Studi Teknik Informatika Fakultas Sains dan Teknologi Universitas Raharja \\ Email :aa gusirawan.email@gmail.com, *2²udianto@ unbaja.ac.id, \\ ${ }^{3}$ rizka.desiana@raharja.info
}

\begin{abstract}
ABSTRAK
Tingkat Penyerapan mahasiswa oleh dunia kerja merupakan bagian penting dalam mendukung kinerja perguruan tinggi.Produktivitas perguruan tinggi dalam mencetak lulusan kadang tidak dibarengi dengan upaya kampus dalam memfasilitasi mahasiswa untuk mendapatkan lapangan pekerjaan yang sesuai dengan bidang kompetensi mereka. Kebutuhan stakeholder yang berkepentingan perlu difasilitasi dengan sebuah media yang dapat menjembatani kepentingan tersebut. Aplikasi Bursa kerja bagi alumni dapat menjembatani kepentingan antara yang membutuhkan pekerja dengan pihak yang membutuhkan pekerjaan itu dalam hal ini alumni melalui universitas. Untuk membangun sistem menggunakan framework Codeigniter yang ditulis dengan bahasa PHP yang merupakan bahasa untuk membangun sistem berbasis web. model yang digunakan adalah dengan menggunakan prototype. Aplikasi diharapkan dapat menyediakan layanan berupa informasi lowongan pekerjaan, dimana dapat melibatkan stakeholder yang berkepentingan baik itu dari industri, universitas dan alumni.
\end{abstract}

Kata kunci : Lowongan kerja, Codeigniter, prototype

\begin{abstract}
The level of student absorption by the world of work is an important part of supporting higher education performance. Higher education productivity in producing graduates is sometimes not accompanied by campus efforts to facilitate students to find jobs that are in accordance with their field of competence. The needs of interested stakeholders need to be facilitated by a media that can bridge these interests. The job fair application for alumni can bridge the interests of workers who need workers and those who need the job, in this case alumni through universities. To build a system using the Codeigniter framework written in PHP, which is a language for building web-based systems. the model used is to use a prototype. The application is expected to provide services in the form of job vacancy information, which can involve interested stakeholders from industry, universities and alumni.
\end{abstract}


Keywords: job vacancies, Codeigniter, prototype

\section{LATAR BELAKANG}

Daya serap alumni di dunia kerja merupakan salah satu yang menjadi cita-cita dalam meningkatkan kualitas dari sebuah perguruan tinggi. Setiap tahunnya ada ribuan bahkan ratusan ribu lulusan dari berbagai perguruan tinggi dan dari berbagai bidang keilmuan yang ikut berebut dalam mendapatkan pekerjaan. Kualifikasi dan ketersediaan lapangan pekerjaan menjadi permasalahan yang muncul kemudian. Tidak terkecuali universitas serang raya. Kampus yang berdiri sejak 2008 ini juga memiliki tujuan untuk meningkatkan daya serap alumninya di lingkungan industri.

Ketersediaan sarana untuk mempublikasikan informasi terkait lowongan kerja dikampus masih menjadi masalah yang dihadapi. Informasi disampaikan dalam bentuk pamflet yang ditempel dipapan informasi pada fakultas masing-masing. Penyebaran terbatas hanya dilingkungan kampus. Sedangkan informasi yang juga disebarluaskan dengan menggunakan media social seperti facebook bukan tanpa masalah dikarenakan tidak semua alumni memiliki akun facebook atau aktif menggunakan facebook sehingga tidak berdampak menyeluruh terhadap alumni yang sedang mencari lowongan pekerjaan.

Pelamar pekerjaan dalam mencari informasi pekerjaan masih menggunakan cara-cara konvensional, yaitu dengan dating keperusahaan untuk melihat papan informasi (Yuliani \& Aries, 2015), ataupun melihat informasi dari Koran ataupun media cetak lainnya. Begitupun dengan perusahaan yang ingin membuka lowongan pekerjaan, mereka harus mengeluarkan biaya yang cukup besar (Setiani, 2013). Beberapa perusahaan besarmaupun kecil menyediakan informasi lowongan kerja melalui media cetak seperti koran (Darmastuti, 2012), ataupunmenggunakanjasapencarikaryawan. Prosespencariankerja dan proses rekrutmen seperti diatas dinilai kurang efektif dan efisien dari segi biaya dan waktu. Selain itu, jumlah pencari kerja semakin meningkat 300 persen seiring melonjaknya jumlah pengangguran (Panduwinata,2017).

Untuk itu maka sarana penyedia informasi resmi tentang lowongan pekerjaan yang melibatkan unsur-unsur terkait perlu untuk dibuat, mengingat bahwa sarana tersebut dapat menjembatani antara penyedia lapangan pekerjaan, pihak universitas dan alumni itusendiri. Aplikasi yang dibangun berbasis web sehingga dapat menyebarluaskan informasi secara online, memberikan akses informasi mencakup wilayah yang lebih luas dan tidak terikat dengan satuan waktu, tergantung pada kapan penerima informasi mengakses informasi tersebut. Kemampuan web dalam menyebarkan informasi didukung ketersediaan infrastruktur untuk menyimpan, mengolah dan mendistribusikan informasi akan mendukung misi universitas dalam memberikan sumbangsih kepada masyarakat.

Aplikasi yang dibangun diharapkan dapat meningkatkan daya serap mahasiswa didunia kerja, dan dapat membantu mendistribusikan informasi dari penyedia lapangan pekerjaan baik itu perusahaan swasta maupun BUMN yang membutuhkan Sumber daya manusia sesuai bidang kualifikasi yang ada di universitas serang raya.

\section{Metode penelitian}


Penelitian ini bertujuan untuk mengembangkan program komputer sebagai sistem informasi bursa kerja untuk alumni universitas serang raya, dengan menggunakan model prototype. "Metode Prototype merupakan metode yang dapat menjembatani ketidakseraisan antara pengguna dan pembuat sistem.Karena dibangun komunikasi yang intens antara pengembang dan pengguna aplikasi tersebut (Pressman, 2012: 50)" [1].

Model prototype adalah siklus proses pengembangan (development) sistem terdiri dari 3 tahapan yaitu: (1) tahap diskusi dengan pihak yang menjadi subjek peneitian, (2). Pembuatan prototype, dan (3) evaluasi dan testing. Ketiga tahapan dalam model prototype dilakukan secara berurutan dan berulang sampai didapatkan prototype yang dinginkan oleh subjek penelitian.

Data alumni digunakan dalam penelitian ini, selain itu juga data perusahaan dan lowongan pekerjaan yang ditawarkan oleh perusahaan. Teknik pengumpulan datanya anatara lain: (1) Wawancara, dengan mewawancarai bagian biro kemahasiswaan dan juga biro akademik untuk mendapatkan gambaran sistem yang sedang berjalan. (2) Studi pustaka, dengan mengumpulkan dokumen-dokumen dan teori dari buku untuk mengembangkan aplikasi bursa pada Universitas serang Raya

\section{Hasil dan pembahasan}

\subsection{Analisa kebutuhan Sistem}

a. Kebutuhan Hardware

Analisa kebutuhan hardware merupakan rincian kebutuhan perangkat keras yang digunakan untuk mengembangkan sistem. Berikut adalah prangkat keras yang dibutuhkan untuk mengembangkan prototype : 
Tabel 4.1 Kebutuhan hardware

\begin{tabular}{|l|l|l|l|}
\hline NO & Perangkat keras & Spesifikasi & Fungsi \\
\hline 1 & Laptop & $\begin{array}{l}\text { Prosesor inter } \\
\text { core i5 } \\
- \text { Ram 4GB } \\
\end{array}$ & $\begin{array}{l}\text { Alat untuk } \\
\text { membuat aplikasi } \\
\text { dan dokumentasi }\end{array}$ \\
\hline 2 & Handphone & $\begin{array}{l}\text { OS android, } \\
\text { Snapdragon 660, ram } \\
\text { 6GB ROM 64GB }\end{array}$ & Modem internet \\
\hline 4 & Printer & & Cetak \\
& & & Dokumentasi \\
\hline
\end{tabular}

b. Kebutuhan software

Kebutuhan software merupakan daftar perangkat lunak yang dimanfaatkan untuk melakukan penelitian ini, antara lain :

Tabel 4.2 Kebutuhan software

\begin{tabular}{|l|l|l|l|}
\hline No & Nama Software & Spesifikasi/versi & Fungsi \\
\hline 1 & Package XAMPP & Versi 3.2 & $\begin{array}{l}\text { Terdiri dari server } \\
\text { apache, database } \\
\text { mysql dan PHP } \\
\text { linterpreter }\end{array}$ \\
\hline 2 & Geany editor & Versi 1.5 & $\begin{array}{l}\text { Editor untuk } \\
\text { membuat } \\
\text { pemrograman } \\
\text { PHP }\end{array}$ \\
\hline 3 & Codeingiter & Versi 3.1.10 & Framework PHP \\
\hline 4 & Bootstrap & & $\begin{array}{l}\text { Framework css } \\
\text { untuk membuat } \\
\text { halaman web }\end{array}$ \\
\hline
\end{tabular}

c. Kebutuhan pengguna

Analisa Pengguna atau brainware merupakan rincian siapa saja user yang terlibat atau yang menggunakan sistem dan hak akses user tersebut dalam sistem.

Tabel 4.3 kebutuhan pengguna

\begin{tabular}{|l|l|l|}
\hline No & Pemgguna & Hak akses \\
\hline 1 & User & $\begin{array}{l}\text { Daftar, login, kelola loker, } \\
\text { merevier lamaran }\end{array}$ \\
\hline 2 & Alumni & $\begin{array}{l}\text { Login, Melihat loker, } \\
\text { melamar loker, kelola data } \\
\text { alumni }\end{array}$ \\
\hline 3 & Admin & $\begin{array}{l}\text { Login, setujui perusahaan, } \\
\text { memantau proses }\end{array}$ \\
\hline
\end{tabular}




\subsection{Perancangan Sistem}

Hasil penelitian ini salah satunya berupa perancangan sistem Bursa kerja dengan menggunakan UML "UML (Unified Modelling Language) adalah sebuah atandar yang digunakan untuk menjelaskan kebutuhan, anasila dan perancangan serta menggambarkan struktur pembrograman berorientasi objek [2]. Sedangkan menurut feri sulianta dan fajri rahmat umbara "UML adalah kumpulan diagram yang sudah memiliki standar pemba ngunan perangkat lunak berbasis objek"[3]. Pembuatan model dimaksudkan untuk membuat permasalahan terlihat menjadi sederhana, sehingga permasalahan yang rumit menjadi mudah untuk dipahami. Berikut adalah diagram-diagram yang dihasilkan :

\section{Usecase Diagram}

"diagram usecase adalah penggambaran perilaku sistem yang dibuat dimana terdapat didalamnya interaksi antara aktor dengan sistem (Rosa \& Shalahuddin 2015:155),"[2]. Berikut usecase sistem bursa kerja :

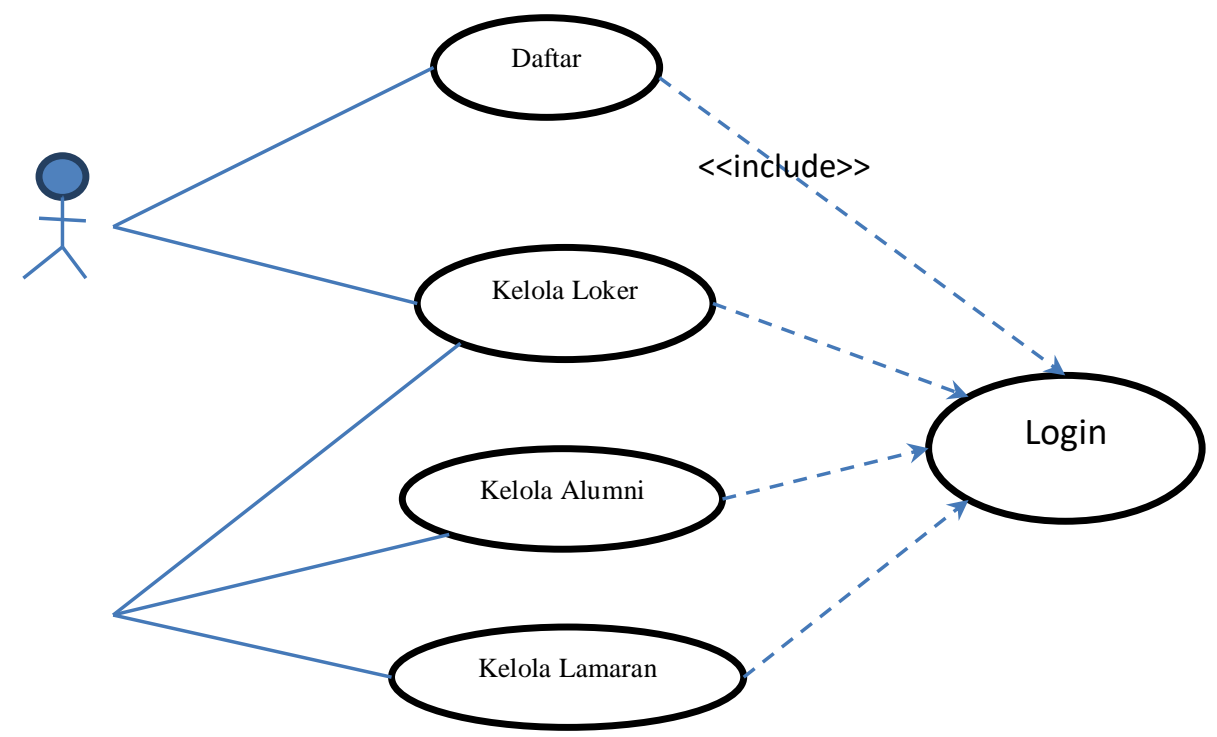

<<include >>

<<include>>

<<include >>

Gambar 1 Usecase Sistem bursa kerja

2. Class diagram

"Diagram kelas menggambarkan sistem sebagai kelas-kelas beserta pendefinisian kelas tersebut baik itu atribut maupun perilaku kelas itu sendiri. (rosa dan sholehuddin 2015:141)" [2]. Sehingga Class diagram dapat diartikan diagram yang menggambarkan hubungan antar objek dengan objek lainnya dalam suatu lingkup sistem yang sama.

Berikut diagram class yang dirancang untuk sistem bursa kerja: 
ISSN: 2461-1409

Online ISSN: 2655-5298

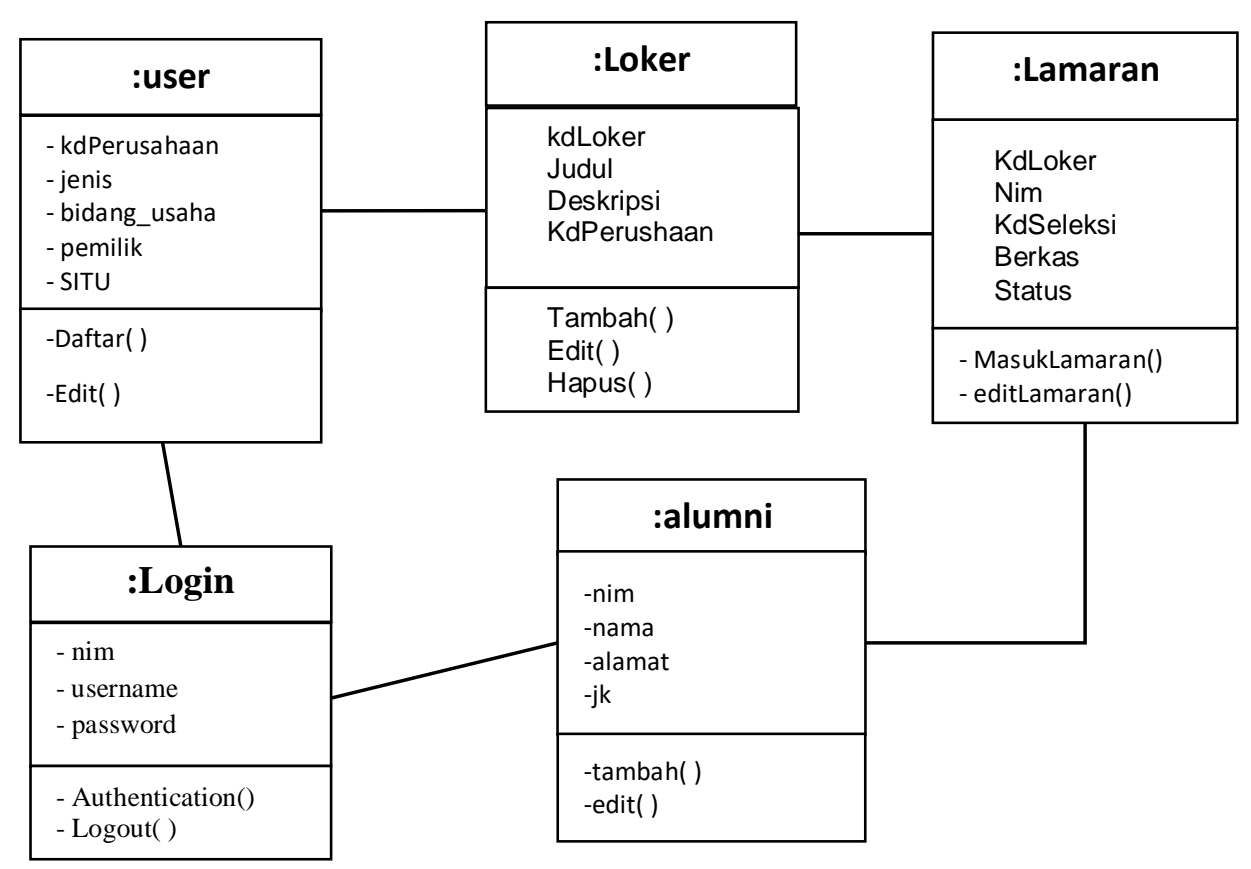

Gambar 2 Class diagram Sistem Bursa Kerja

3. Activity diagram

Menurut hendini A. (2016) "Diagram aktifitas merupakan diagram behavior yang menggambarkan perilaku atau kegiatan dari sistem bagian dari UML [5]. Sedangkan menurut Rosa \& Shalahuddin (2015:161) menyatakan Diagram aktifitas menggambarkan suatu aliran aktifitas dari fungsionalitas atau dari menu-menu yang ada pada program perangkat lunak. Yang menjadi focus pada diagram aktifitas adalah bagaimana perilaku sistem bukan perilaku aktor [2] Berikut adalah activity diagram dalam sistem Bursa Kerja :

a. Diagram Activity Login 


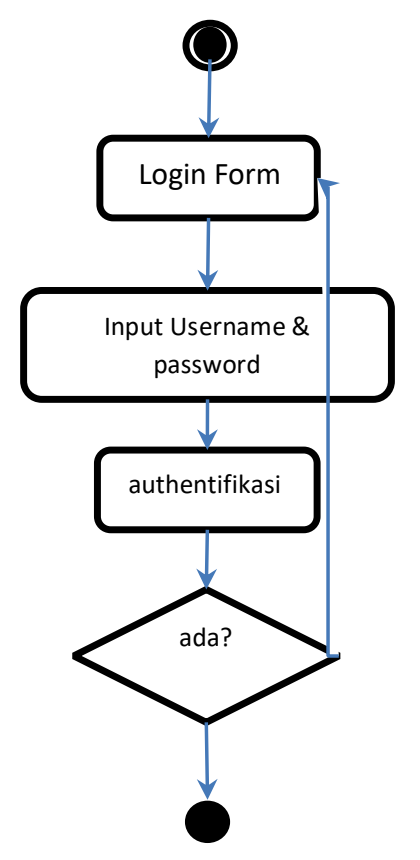

Gambar 3 Diagram activity Login

b. Diagram activity Kelola loker (user) 


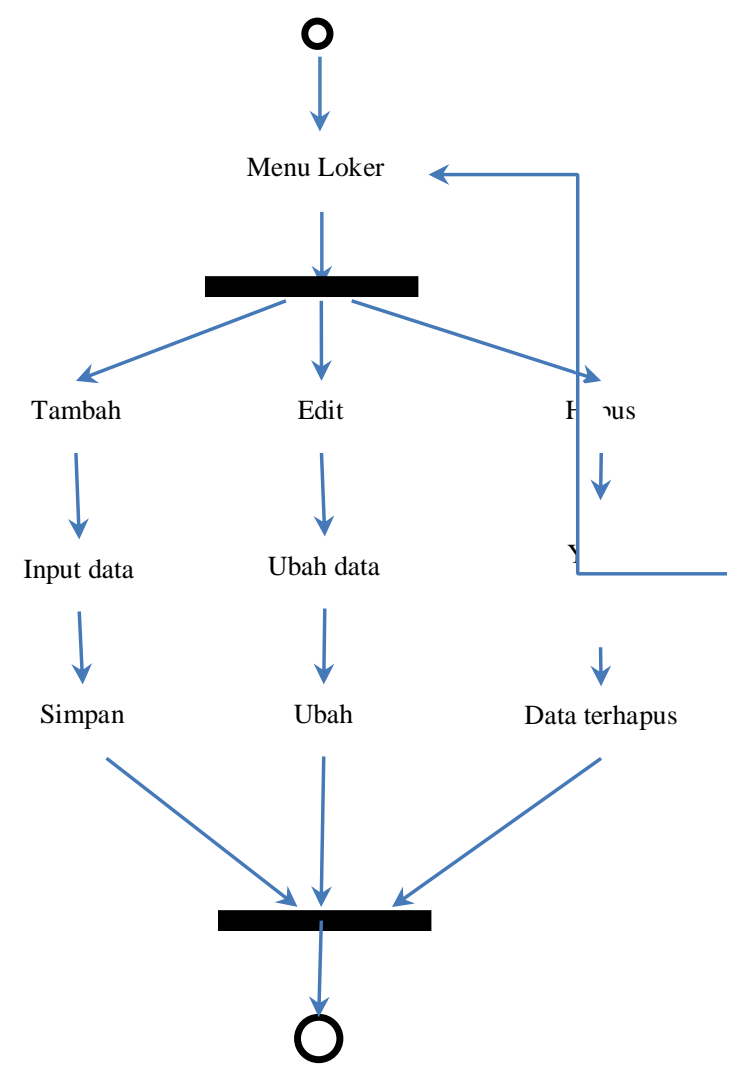

Gambar 4 Diagram activity Kelola Loker

c. Diagram activity pengajuan lamaran (alumni)

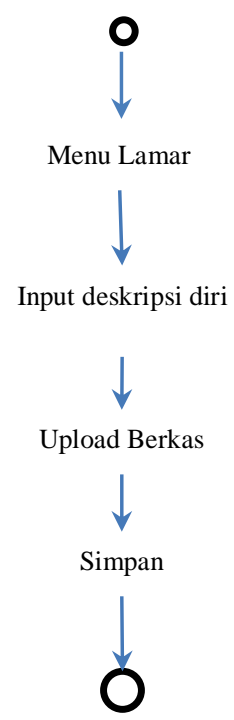

Gambar 5 Diagram activity pengajuan lamaran (alumni) 
d. Diagram activity update status lamaran (user )

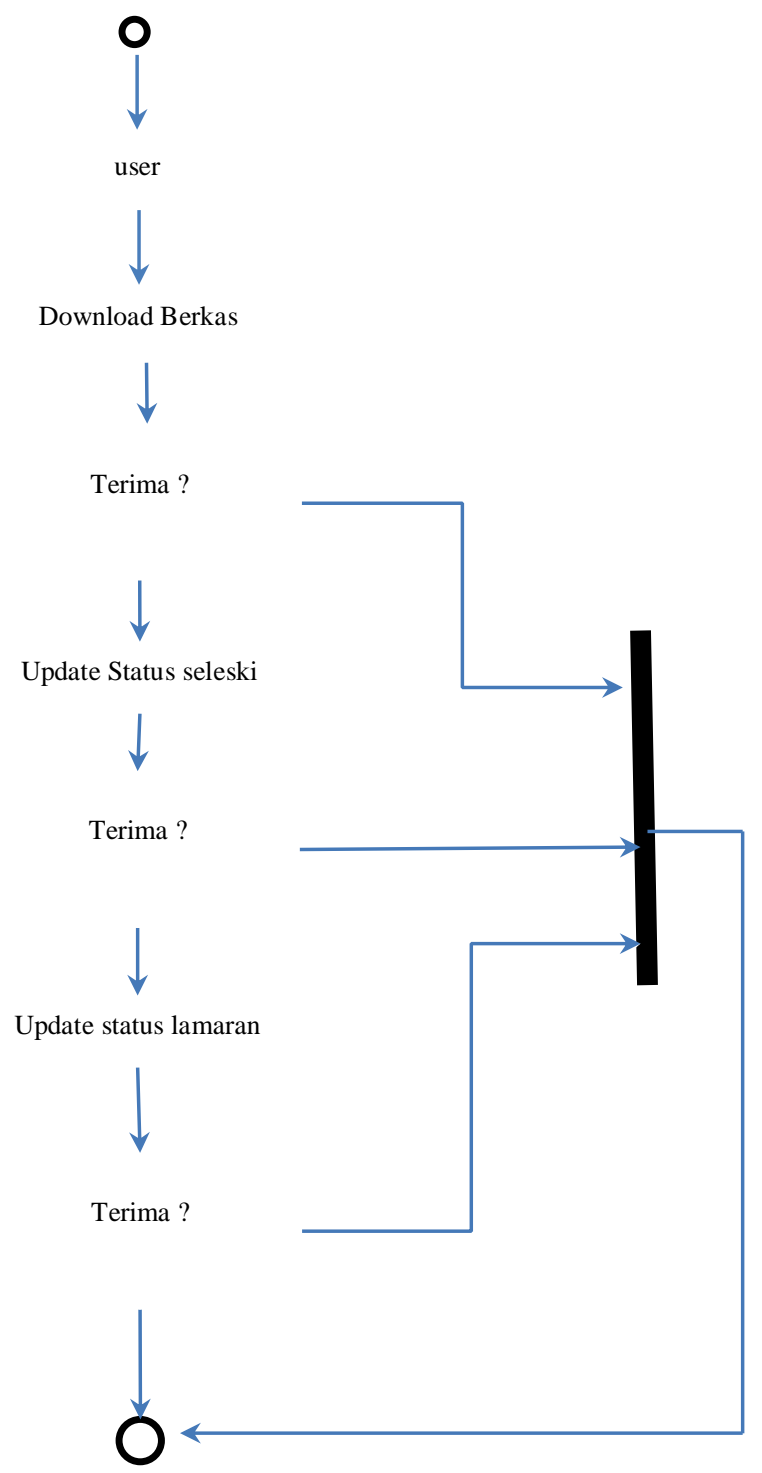

Gambar 6 Diagram activity update status lamaran (user)

4. Sequence diagram

Rosa \& Shalahuddin (2015:165) Menyebutkan: Diagram sekuen menggambarkan perilaku objek yang bersesuaian dengan usecasenya dengan menambahkan waktu hidup dari sebuah objek dan pesan apa yamg dikirimkan ataupun yang diterima. Oleh sebab itu untuk membuat diagram sekuen maka terlebih dahulu diinventarisir objek apa saja yang terlibat dalam sebuah usecase beserta fungsi dari kelas yang membuat objek tersebut [2]. 
Secara mudahnya "sequence diagram adalah gambaran proses berupa kronologi (urutan) perubahan secara logis sesuai dengan diagram usecasenya dengan tujuan mengasilkan sesuatu(Haviluddin, 2011)". [5].

a. Diagram Sequence Daftar

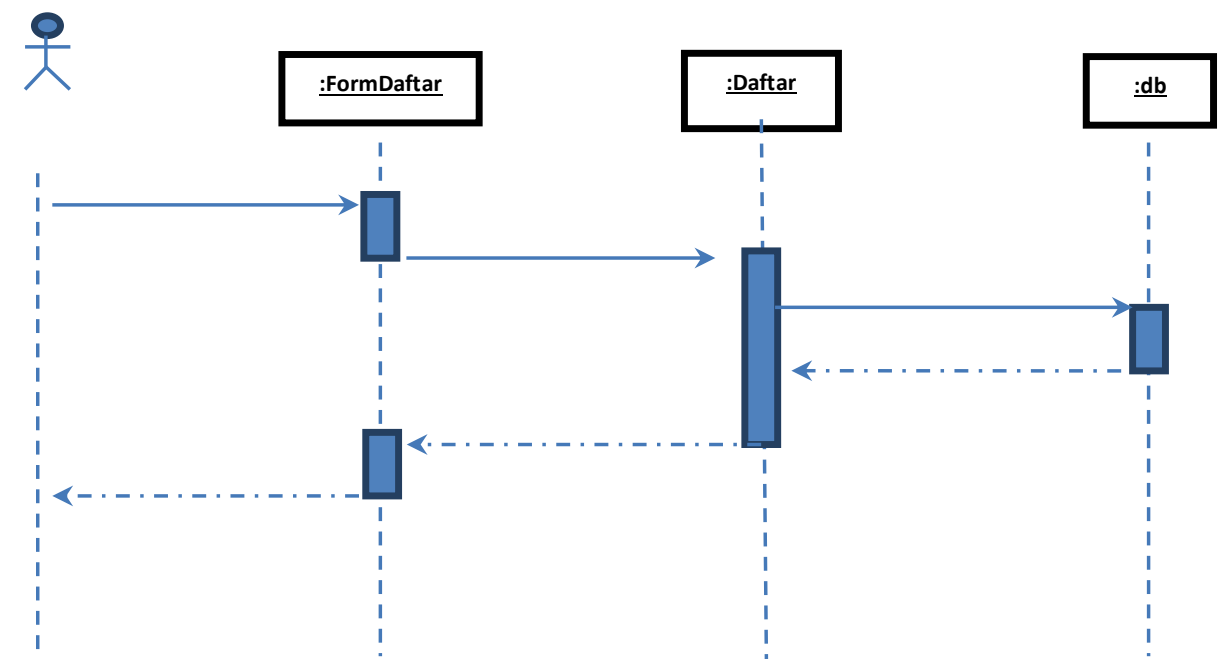

report()

tampilPesan()

\section{:Perushaan}

Input data

SendData( )

Insert()

Status()

gambar 7 Diagram Sequence Daftar 
b. Diagram sequence

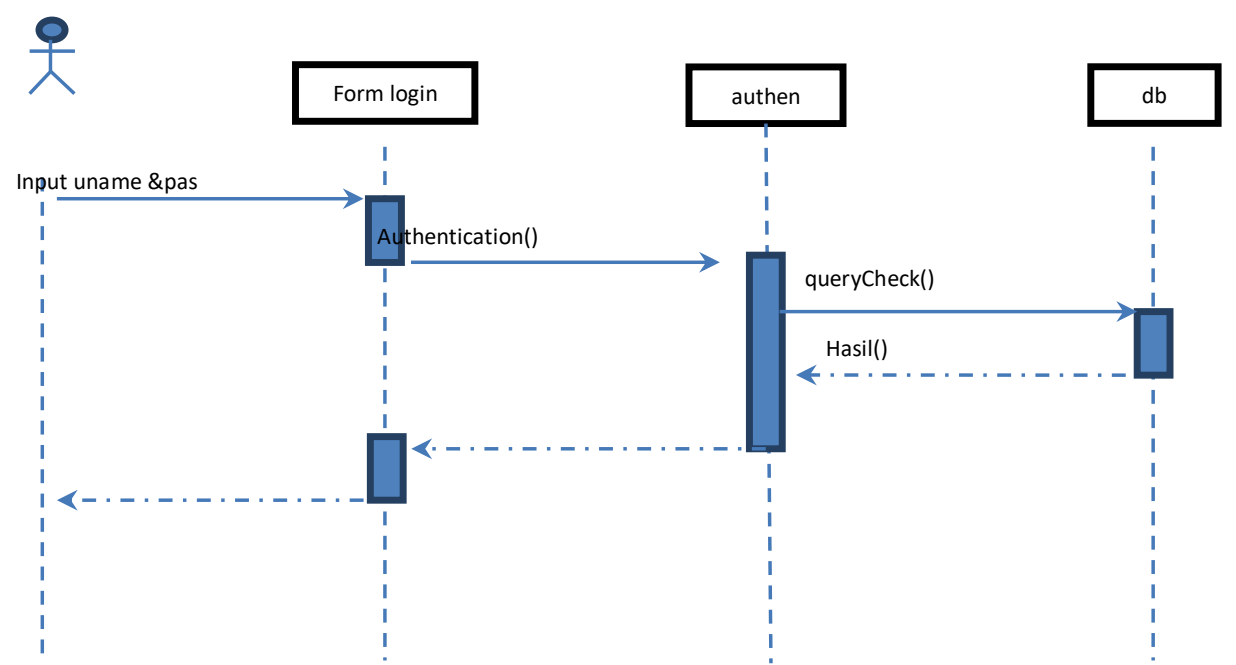

Login

Status()

tampilPesan()

:User

Gambar 8 Diagram SequenceLogin

c. Diagram Sequence kelola loker

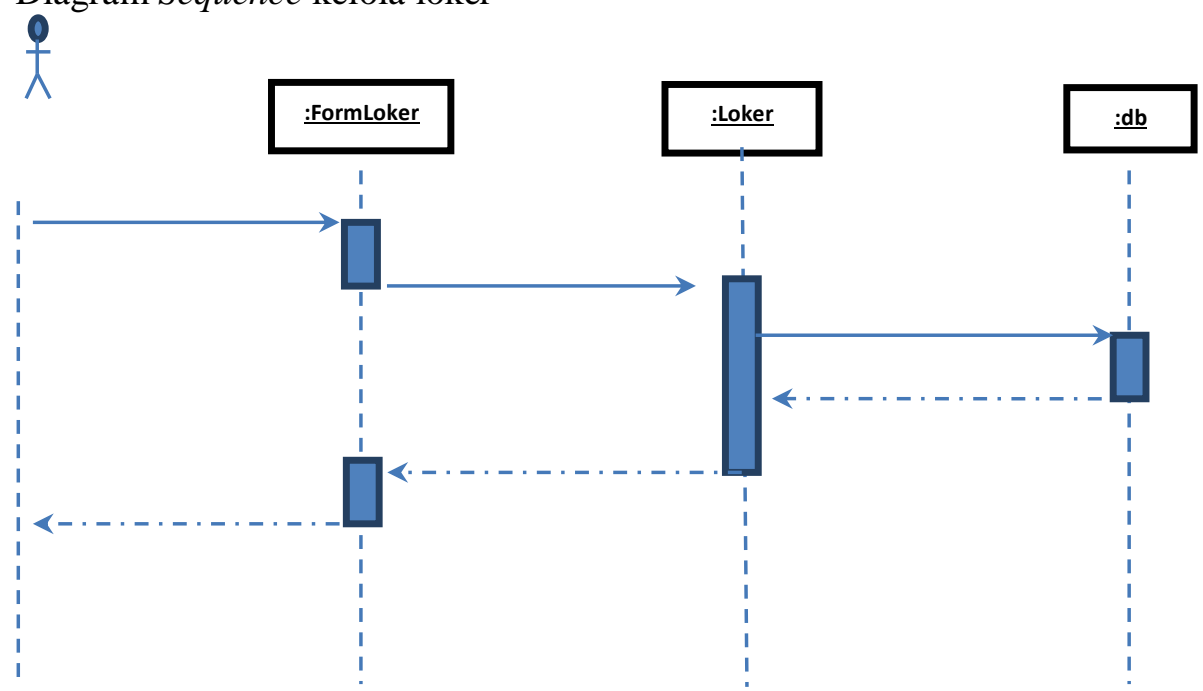

Status()

tampilPesan()

InputLokert

Vol.7 No.1 - Februari 2021 
DataInsert()

Insert()

statusINsert()

:perusahaan

Gambar 9 Diagram Sequence Kelola Loker

d. Diagram sequence kelola lamaran

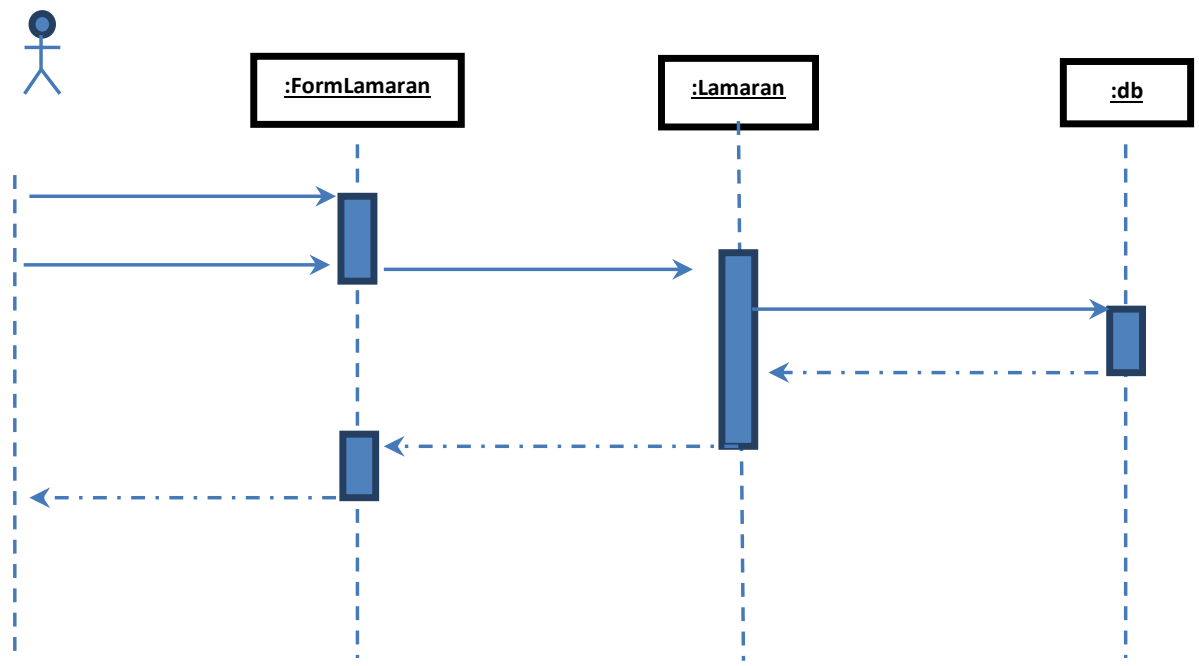

Status()

tampilPesan()

InputLamaran

DataInsert()

Insert()

statusINsert()

UploadBerkas

:Alumni

Gambar 10 Diagram Sequence Kelola Lamaran

e. Diagram sequence kelola alumni 


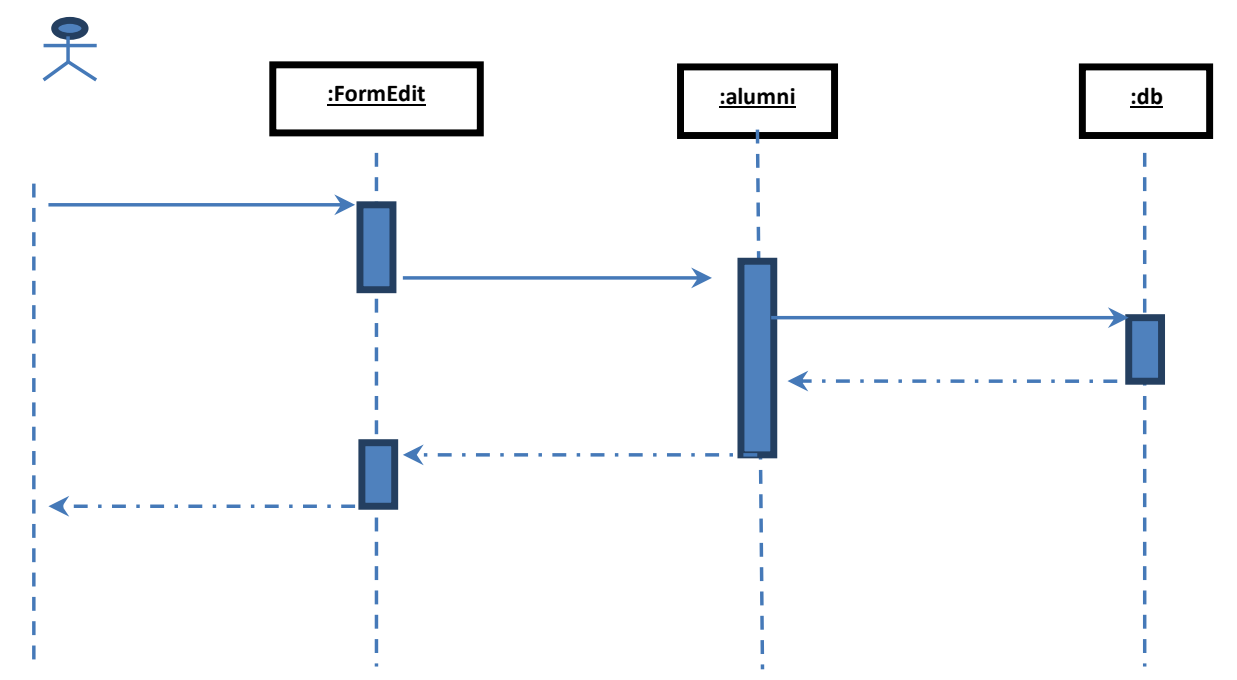

Status()

tampilPesan()

Update Data

DataUpdate()

update()

statusUpdate()

: Alumni

Gambar 11 Diagram Sequence kelola Alumni

3.3 Hasil

1. Halaman home

Halaman home adalah halaman awal ketika sistem diakses, halaman ini adalah halaman static. 


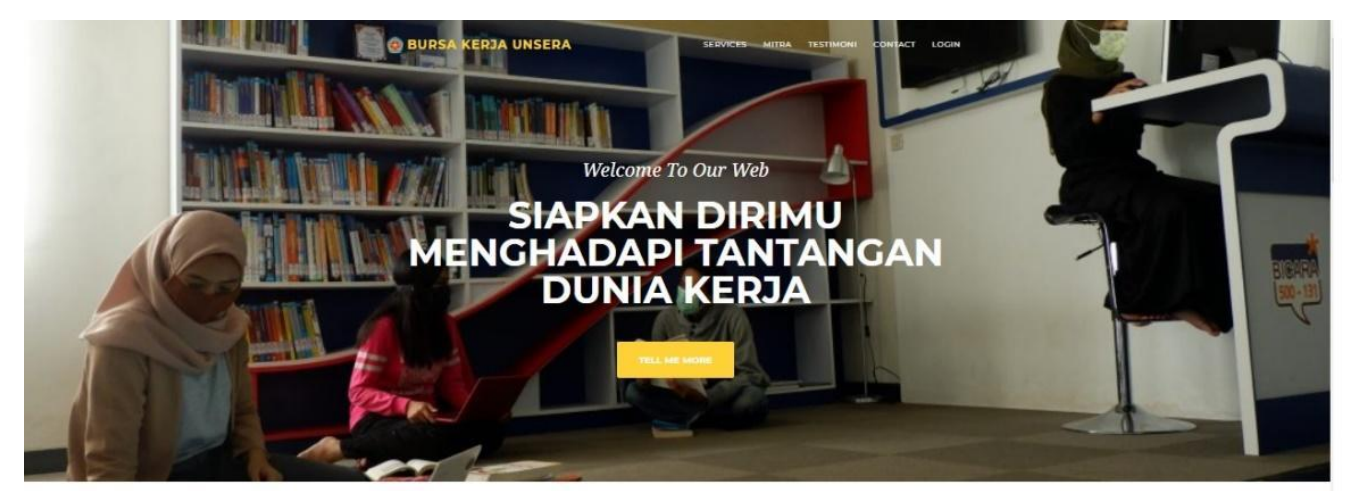

LAYANAN

Gambar 12 Halaman Home

2. Halaman login user

Halaman login untuk pengguna sistem dari pihak user perusahaan mitra.User mitra menginputkan username dan password sesuai dengan akun yang sudah didaftarkan disistem.

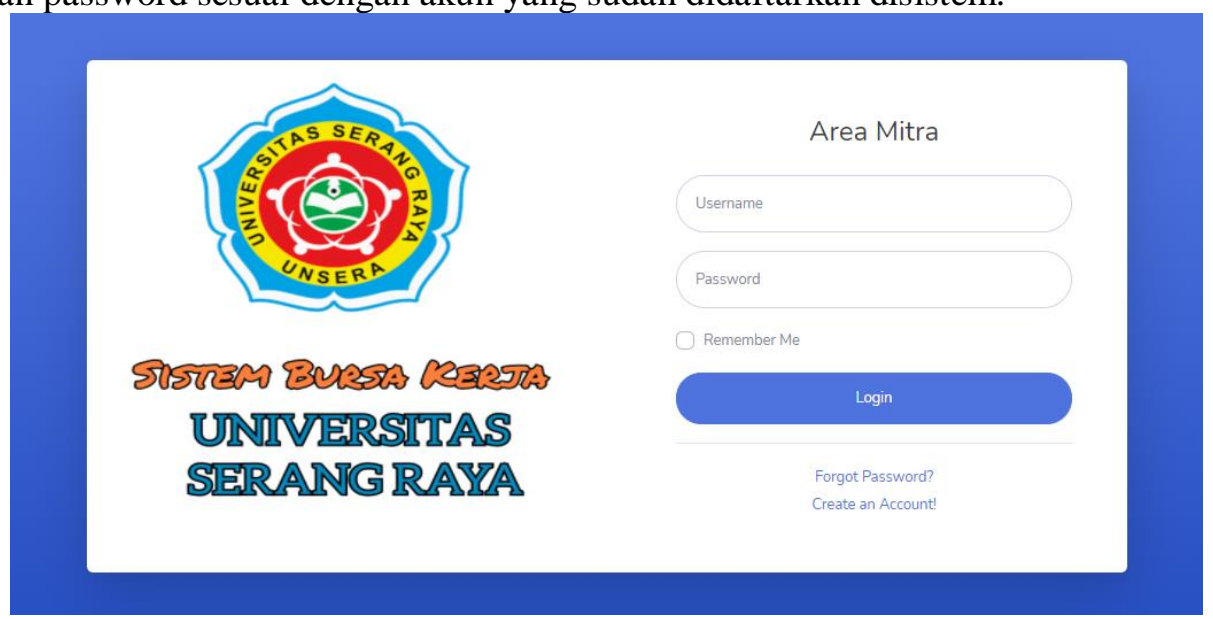

Gambar 13 Halaman Login User Mitra

3. Halaman beranda user mitra

Halaman yang menampilkan beranda user. Halaman awal ini menampilkan list lowongan pekerjaan yang pernah di posting oleh user mitra disistem. Halaman ini bisa mengakses form input data lowongan kerja (loker), halaman edit dan hapus lowongan. 
ISSN: 2461-1409

Online ISSN: 2655-5298

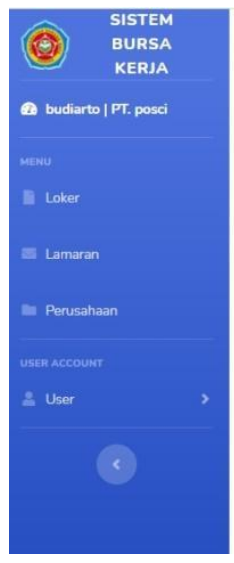

\section{Data Lowongan Kerja}

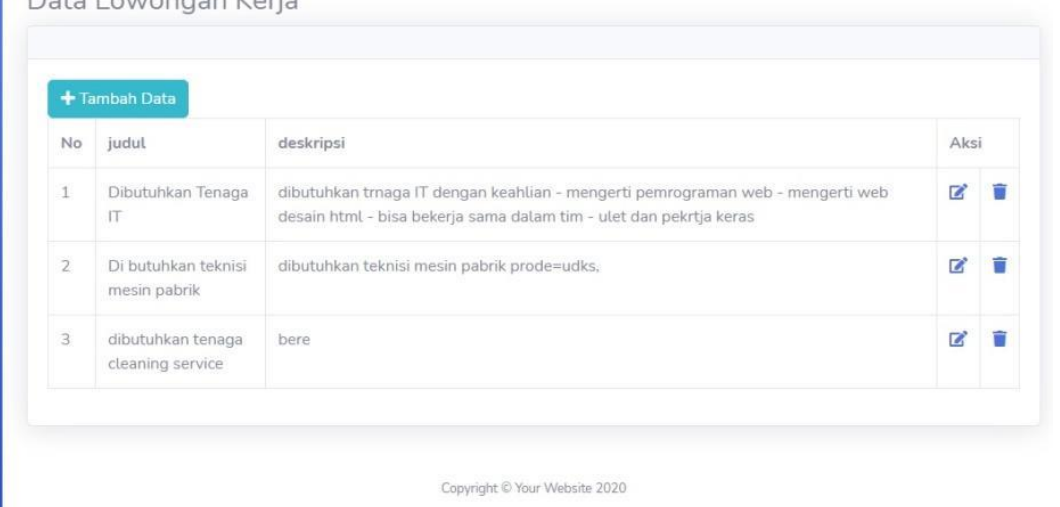

Gambar 14 Halaman beranda User MItra

4. Halaman seleksi lamaran

Halaman ini menampilkan status lamaran berdasarkan pekerjaan yang ditawarkan oleh user mitra disistem.Pada halaman ini user mitra dapat memperbaharui status lamaran alumni, mulai dari status berkas persyaratan, status hasil seleksi dan status diterimanya lamaran alumni.

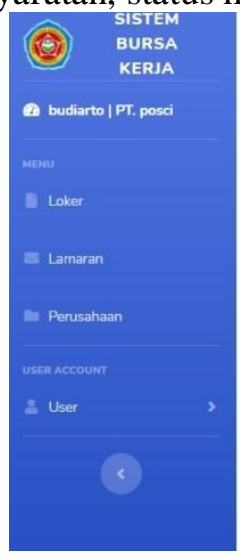
Lamaran Masuk

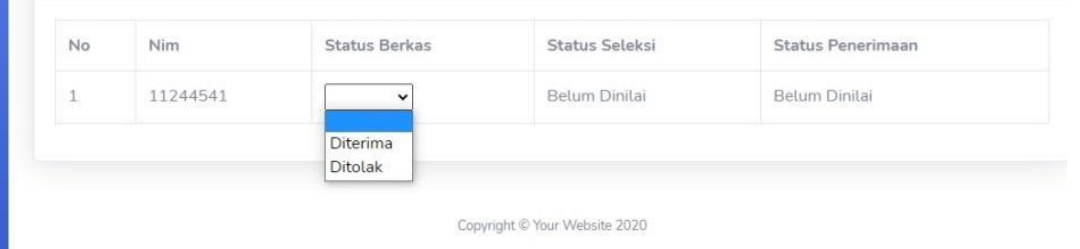

Gambar 15 Halaman Lamaran Masuk

5. Halaman beranda alumni

Halaman ini menampilkan daftar lowongan pekerjaan (loker) yang sudah di post oleh user mitra dari pesuahaan.Dihalaman ini juga ada filter berdasarkan bidang pekerjaan, dari sini alumni bisa mengakses halaman untuk upload berkas persayratan lamaran. 

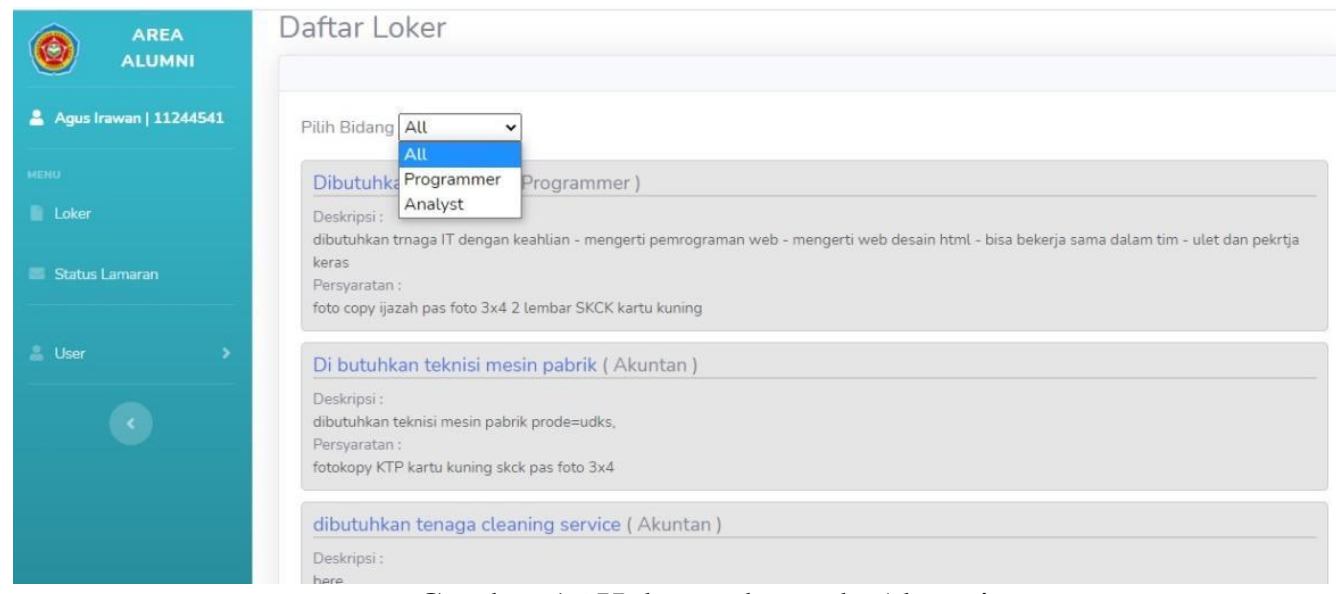

Gambar 16 Halaman beranda Alumni

6. Halaman status lamaran alumni

Halaman ini menampilkan status proses lamaran, mulai dari pemberkasan, hasil seleksi dan status alumni apakah diterima atau ditolak.

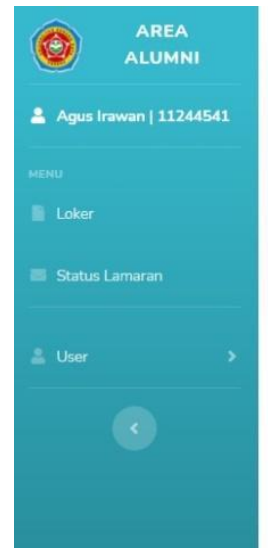

Status lamaran alumni

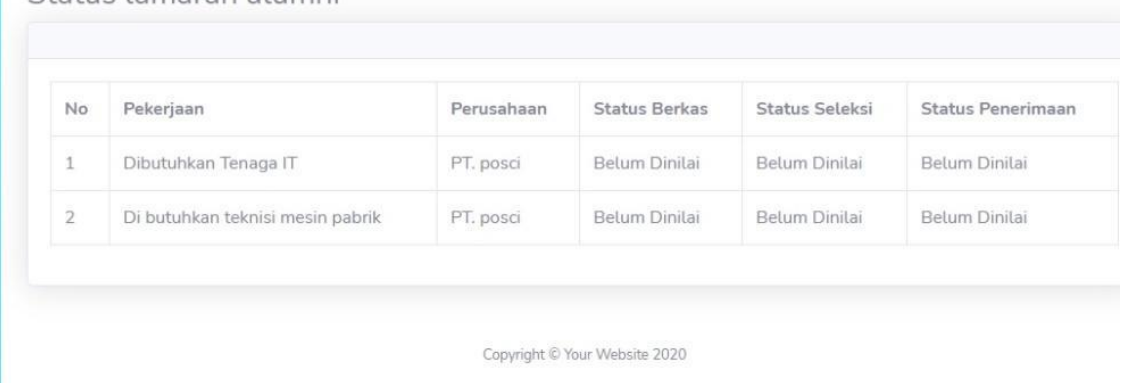

Gambat 17 halaman status Lamaran Alumni

\section{Kesimpulan}

Dari penelitian ini dapat disimpulkan beberpa hal antara lain :

1. Penelitian Sistem bursa kerja pada universitas serang raya telah menghasilkan sebuah prototype sistem bursa kerja.

2. Sistem yang dibangun memfasilitasi kebutuhan perusahaan mitra akan tenaga kerja dibidanbidang yang ada di Universitas serang raya dan kebutuhan Alumni akan lapangan pekerjaan.

\section{Saran}

1. Ada kekurangan seabgai batasan dalam penelitian ini, terkait dengan seleksi yang bisa dilakukan secara online yang tidak difasilitasi oleh sistem. Diharapkan pada penelitian selanjutnya dapat dikemabangkan kearah penambahan kemampuan tersebut.

2. Sistem dapat ditempatkan di server internal kampus, dengan di uji secara mendetail terkait keamanan sistem oleh tim Bapsi universitas serang raya, agar dapat dimanfaatkan sebagai bagian dari sistem terpadu universitas Serang Raya. 


\section{DAFTAR PUSTAKA}

[1] Pressman, Roger S. 2012. RekayasaPerangkatLunakPendekatanPraktisi.Edisi 7. Yogyakarta : Andi

[2] A.S, Rosa dan shalahuddin, M. 2015. Rekayasaperangkatlunakterstruktur dan berorientasiobejek. Informatika. Bandung.

[3] Ade Hendini. (2016). Pemodelan UML SistemInformasiMonitorigPenjualan dan Stok Barang (StudiKasus: DostroZhezha Pontianak). JurnalKhatulistiwa, Vol. 4 No. 2.

[4] Codeigniter, Diakses pada lamanhttp://codeigniter.com pada tanggal 12 maret 2020

[5] Haviluddin. (2011). MemahamiPenggunaan UML (Unified Modelling Language). Jurnal InformatikaMulawarman. Retrieved from http://ejournals.unmul.ac.id/index.php/JIM/article/view/16 [6] Yuliani, Y., \& Aries, R. (2015). aplikasigerailayananinformasikerja (glik) (studikasus:dinastenagakerja dan transmigrasiprovinsijawa barat). MajalahIlmiah UNIKOM, 13(1). [7] Setiani, B. (2013). Kajian SumberDayaManusiaDalam Proses Rekrutmen Tenaga Kerja Di Perusahaan. JurnalIlmiahWidya, 1(1), 38-44.

[8] Darmastuti, D. (2012). ImplementasiMetode Simple Additive Weighting ( Saw ) DalamSistemInformasiLowonganKerjaBerbasis Web DestriyanaDarmastuti, 16(2), 1-6. [9] Panduwinata, A. (2017). JumlahPencariKerjaMeningkat 300 PersenSeiringMelonjaknya Pengangguran. Wartakotalive.com, p.http://wartakota.tribunnews.com/2017/07/03. 